\title{
Phylogenetic Analysis of "Candidatus Phytoplasma australiense" Reveals Distinct Populations in New Zealand
}

\author{
Mark T. Andersen, Richard D. Newcomb, Lia W. Liefting, and Ross E. Beever
}

First and second authors: HortResearch, Private Bag 92169, Auckland, New Zealand; third author: AgriGenesis Biosciences Ltd., P.O. Box

50, Auckland, New Zealand; and fourth author: Landcare Research, Private Bag 92170, Auckland, New Zealand. Accepted for publication 10 March 2006.

\section{ABSTRACT}

Andersen, M. T., Newcomb, R. D., Liefting, L. W., and Beever, R. E. 2006. Phylogenetic analysis of "Candidatus Phytoplasma australiense" reveals distinct populations in New Zealand. Phytopathology 96:838-845.

The phytoplasma "Candidatus Phytoplasma australiense" has been reported from New Zealand and Australia, where it has been associated with a range of host plants, especially since the 1970s. Partial tuf gene sequences of 36 New Zealand (NZ) isolates from four different host genera revealed nine different variants, which clustered into two distinct groups without any obvious correlation with host or geographic region. Phylogenetic analysis of these sequences, together with those available from Australian isolates, revealed three distinct clades: one found solely in Australia, one found solely in NZ, and a third with representatives from both countries. These divisions are consistent with differences observed in the 16-23S rRNA internal transcribed spacer region; therefore, we conclude that they represent three distinct subgroups: tuf 1, tuf 2 , and tuf 3 . We estimated a time of divergence for the three clades based on a synonymous substitution rate calculated by comparing the complete tuf gene sequence from the Loofah witches'-broom phytoplasma and "Candidatus Phytoplasma australiense". Using a calibration date of 110 million years, the estimated time to a common ancestor for all clades (6 to 9 million years ago) suggests divergence during the Miocene, well after the geological separation of NZ and Australia.
Phytoplasmas are a group of insect-transmitted prokaryotes (class Mollicutes) associated with diseases of $\approx 1,000$ plant species (29). They are characterized by the lack of a cell wall, small genome size, and a low $\mathrm{G}+\mathrm{C}$ content, with none having been cultured in vitro to date (20). Prior to the development of molecular techniques, phytoplasmas were grouped on the basis of biological properties such as symptoms induced, plant host range, and vector specificity. More recently, the focus has been on comparing genetic variation, through both direct DNA sequence comparisons and the use of restriction fragment length polymorphisms (RFLPs). Initial emphasis has been on the 16S rRNA gene $(1,22,26)$, because of its conservation throughout the prokaryotes. Using this approach, more than 14 distinct phylogenetic groups and, in some instances, subgroups of related phytoplasmas have been recognized $(17,20,41)$. Although delimited primarily on the basis of $16 \mathrm{~S}$ rDNA similarity, other phylogenetic markers, such as the 23S rRNA gene, the 16S-23S rRNA internal transcribed spacer (ITS) regions, and various protein encoding genes, support and, in some cases, extend these groupings (20). The obligate nature of phytoplasmas has hampered formal taxonomic recognition of their variation; however, many of the groups and subgroups are now being recognized as species using the Candidatus concept proposed for unculturable organisms (30). This system groups phytoplasmas into Candidatus spp. on the basis of 16S rRNA sequence similarity. In general, those isolates that are $\geq 97.5 \%$ identical are grouped together in the same Candidatus sp. unless significant differences in biological or genetic properties suggest that they should be classified separately (17).

With the exception of "Candidatus Phytoplasma asteris" (21), variation within these Candidatus spp. has been poorly studied.

Corresponding author: M. T. Andersen

E-mail address: mandersen@hortresearch.co.nz

DOI: 10.1094/PHYTO-96-0838

(C) 2006 The American Phytopathological Society
However, such variation will give clues to host specificity, ecological history, and genetic structuring. Although the 16S rRNA gene can be useful for delineating variation within species, allowing, for example, recognition of 15 subgroups within " $\mathrm{Ca}$. $\mathrm{P}$. asteris" (21), generally it has insufficient variability to reveal intraspecific groupings. The $16 \mathrm{~S}-23 \mathrm{~S}$ rDNA spacer region is more variable, and can be useful in distinguishing closely related groups of phytoplasmas (42). However, the two rRNA operons in phytoplasmas can be different, making it difficult to distinguish variation between paralogous operons within an isolate from orthologous genes between isolates $(23,38)$. Alternatives include protein coding genes such as ribosomal protein genes (16) and the tuf gene, which encodes the elongation factor Tu (EF-Tu) (36). In Mollicutes, including phytoplasmas, the tuf gene is present as a single copy and can be sequenced readily using a polymerase chain reaction (PCR) approach $(6,19)$.

"Candidatus Phytoplasma australiense" is a phytoplasma associated with diseases in New Zealand (NZ) and Australia (11, 24). In NZ, it is associated with diseases of both native and exotic plants, including Phormium yellow leaf (PYL) (25), strawberry lethal yellows (SLY) (3), Cordyline sudden decline (CSD) (2), and Coprosma lethal decline (CLD) (5). In Australia, it is associated with the diseases Australian grapevine yellows (AGY or AUSGY) and papaya dieback (PDB), as well as SLY and strawberry green petal (SGP) $(15,27,32,48)$. The $16 \mathrm{~S}$ rRNA genes in all these examples are at least $99 \%$ similar to each other, indicating that, under the Candidatus system, they form a single species (25). Additionally, phytoplasma has been detected using PCRRFLP analysis in an assortment of other plants in Australia, including Phaseolus vulgaris (37), Catharanthus roseus periwinkle (12), cottonbush, mung bean, and pumpkin (43), and the Australian native shrubs Exocarpus cupressiformis and Jacksonia scoparia (44). Sequence differences have been detected between isolates of "Candidatus P. australiense" when other genomic regions, such as the tuf gene (36), the 16-23S spacer region (32), and the ribosomal protein-encoding ( $r p$ ) operon (43), have 
been examined. In the present study, we investigated variation in the tuf gene in a diverse sample of $\mathrm{NZ}$ isolates of " $\mathrm{Ca}$. $\mathrm{P}$. australiense" to better understand intraspecific variation and to explore possible association of particular variants with host range and geographic distribution, especially in relation to Australian populations.

\section{MATERIALS AND METHODS}

Plant material. Plants showing symptoms of known phytoplasma diseases were sampled from field locations throughout NZ. They consisted of plants from the following four genera, with the number of samples indicated: Coprosma robusta $(n=6)$, Cordyline australis $(n=4), C$. banksii $(n=1)$, Phormium tenax $(n=12)$, and strawberry $(n=14)$ (Table 1$)$. DNA was extracted from $0.3 \mathrm{~g}$ of tissue according to the protocol of Gardiner et al. (14) and resuspended in $100 \mu \mathrm{l}$ of $\mathrm{H}_{2} \mathrm{O}$. DNA was further purified using S300HR, a size-exclusion spin column, as specified by the manufacturer (Amersham Biosciences, UK).

Gene amplification and sequencing. Template DNA (10 to $50 \mathrm{ng}$ ) was amplified as described previously (2), in either a Corbett FTS-1S or FTS-4000 Thermal Sequencer with the following conditions: $94^{\circ} \mathrm{C}$ for $2 \mathrm{~min}, 53^{\circ} \mathrm{C}$ for $1 \mathrm{~min}, 72^{\circ} \mathrm{C}$ for $2 \mathrm{~min}$ for 1 cycle, then $94^{\circ} \mathrm{C}$ for $1 \mathrm{~min}, 53^{\circ} \mathrm{C}$ for $30 \mathrm{~s}$, and $72^{\circ} \mathrm{C}$ for $2 \mathrm{~min}$ for 35 cycles. Reaction conditions were $20 \mathrm{mM}$ Tris-Cl (pH 8.4), $50 \mathrm{mM} \mathrm{KCl}, 200 \mu \mathrm{M}$ dNTPs, $1.5 \mathrm{mM} \mathrm{MgCl}_{2}$, and 0.5 unit of $\mathrm{Taq}$ polymerase (Invitrogen, Carlsbad, CA), with a final primer concentration of $100 \mathrm{nM}$.
Fragments (949 bp in length) of " $\mathrm{Ca}$. P. australiense" tuf gene were generated using primers fTuf AY and rTuf AY (36). Two further primers, Tuf1FA (5'-GATAGTGTAATGCCTCA-3') and Tuf4R (5'-CCTGCTTGAGCAAAATCTA-3') were designed to be used in nested PCR from the fTufAY/rTufAY amplicon. Four primers (two forward and two reverse), designed to distinguish between " $\mathrm{Ca}$ P. australiense" tuf 1 and tuf 2 , are listed in Table 2.

PCR products of the 16-23S spacer region of the rRNA operon were generated using primers P1 (13) and P7 (39). Ambiguities created by insertions and deletions were resolved by sequencing from cloned fragments. The P1/P7 PCR fragment of NZSb11 was cloned into pGEM-T easy (Promega Corporation, Madison, WI) according to the manufacturer's specifications, and DNA was prepared using the QIAGEN Plasmid miniprep kit according to their protocols (QIAGEN GmbH).

DNA sequencing was conducted using an ABI Prism 377 (PE Applied Biosystems, Foster City, CA) with Big Dye Terminator chemistry. Unless stated otherwise, PCR products were sequenced, with primers and salts removed by passing samples through an S300HR size-exclusion column (Amersham Biosciences). Primers used for sequencing were fTufAY, rTufAY, Tuf1FA, Tuf4R for the tuf gene, NP6AF (23), and P7 for the 1623S SR. Universal sequencing primers SP6 and T7 were used for further sequencing of cloned fragments. All isolates were sequenced at least twice from separate PCR reactions. No differences between sequences of each isolate were observed.

Database sequences. GenBank accession numbers of tuf gene sequences used for comparison are Loofah witches'-broom

TABLE 1. Isolates of "Candidatus Phytoplasma australiense" with host plant, geographical location, tuf gene variation, and GenBank accession number

\begin{tabular}{|c|c|c|c|c|c|}
\hline Isolate & Host plant & Geographical location & Tuf variant group & Tuf gene clade & Accession number \\
\hline $\mathrm{NZPh} 1$ & Phormium tenax & Auckland & I & 2 & DQ094772 \\
\hline $\mathrm{NZPh} 2$ & Phormium tenax & Auckland & I & 2 & $\ldots$ \\
\hline $\mathrm{NZPh} 3$ & Phormium tenax & Northland & II & 2 & DQ094773 \\
\hline $\mathrm{NZPh} 4$ & Phormium tenax & Northland & II & 2 & $\ldots$ \\
\hline NZPh5 & Phormium tenax & Bay of Plenty & III & 2 & DQ094774 \\
\hline NZPh6 & Phormium tenax & Northland & IV & 2 & DQ094775 \\
\hline $\mathrm{NZPh} 7$ & Phormium tenax & Nelson & $\mathrm{V}$ & 2 & DQ094776 \\
\hline NZPh8 & Phormium tenax & Nelson & V & 2 & $\ldots$ \\
\hline $\mathrm{NZPh} 9$ & Phormium tenax & Wellington & VI & 2 & DQ094777 \\
\hline NZPh10 & Phormium tenax & Taupo & VI & 2 & $\ldots$ \\
\hline NZSb7 & Strawberry cv. Pajaro & Bay of Plenty & VII & 2 & DQ094778 \\
\hline NZPh11 & Phormium tenax & Coromandel & VII & 2 & $\ldots$ \\
\hline NZSb1 & Strawberry cv. Chandler & Bay of Plenty & VII & 2 & $\ldots$ \\
\hline $\mathrm{NZSb} 2$ & Strawberry cv. Pajaro & Waikato & VII & 2 & $\ldots$ \\
\hline NZSb3 & Strawberry cv. Pajaro & Waikato & VII & 2 & $\ldots$ \\
\hline $\mathrm{NZSb} 4$ & Strawberry cv. Camarosa & Bay of Plenty & VII & 2 & $\ldots$ \\
\hline NZSb5 & Strawberry cv. Pajaro & Waikato & VII & 2 & $\ldots$ \\
\hline NZSb6 & Strawberry cv. Camarosa & Bay of Plenty & VII & 2 & $\ldots$ \\
\hline NZSb8 & Strawberry cv. Camarosa & Bay of Plenty & VII & 2 & $\ldots$ \\
\hline NZCp1 & Coprosma robusta & Auckland & VII & 2 & $\ldots$ \\
\hline $\mathrm{NZCp} 2$ & Coprosma robusta & Auckland & VII & 2 & $\ldots$ \\
\hline NZCp3 & Coprosma robusta & Auckland & VII & 2 & $\ldots$ \\
\hline NZCp4 & Coprosma robusta & Auckland & VII & 2 & $\ldots$ \\
\hline NZCp5 & Coprosma robusta & Auckland & VII & 2 & $\ldots$ \\
\hline NZCt1 & Cordyline australis & Auckland & VII & 2 & $\ldots$ \\
\hline $\mathrm{NZCt} 2$ & Cordyline australis & Auckland & VII & 2 & $\ldots$ \\
\hline $\mathrm{NZCt} 3$ & Cordyline australis & Auckland & VII & 2 & $\ldots$ \\
\hline NZSb9 & Strawberry cv. Seascape & Bay of Plenty & VIII & 1 & DQ094779 \\
\hline NZSb10 & Strawberry cv. Pajaro & Waikato & VIII & 1 & $\ldots$ \\
\hline $\mathrm{NZCt} 4$ & Cordyline banksii & Auckland & IX & 1 & DQ094780 \\
\hline NZPh12 & Phormium tenax & Bay of Plenty & IX & 1 & $\ldots$ \\
\hline NZCp6 $6^{b}$ & Coprosma robusta & Bay of Plenty & IX & 1 & $\ldots$ \\
\hline $\mathrm{NZCt5}$ & Cordyline australis & Auckland & IX & 1 & $\ldots$ \\
\hline NZSb11 & Strawberry cv. Pajaro & Bay of Plenty & IX & 1 & $\ldots$ \\
\hline NZSb12 & Strawberry cv. Camarosa & Bay of Plenty & IX & 1 & $\ldots$ \\
\hline NZSb13 & Strawberry cv. Selva & Bay of Plenty & IX & 1 & $\ldots$ \\
\hline NZSb14 & Strawberry cv. Pajaro & Bay of Plenty & IX & 1 & $\ldots$ \\
\hline
\end{tabular}

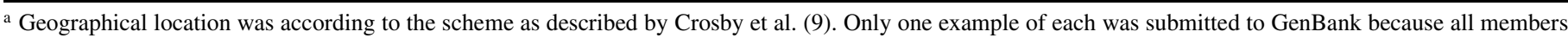
of a variant group are identical.

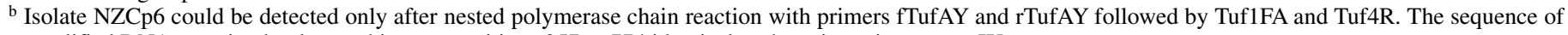
amplified DNA contained polymorphisms at positions 357 to 774 identical to those in variant group IX. 
(AF086617), SLY (AY303552), CBWB (AY303553), CBRYL (AY303554), PYLC (AY303555), SLY1 (AY303556), AGY (AY303557), SGP (AY303571), KV (L46369), and STOLF (L46370). NZ samples sequenced here were: NZPh1 (DQ094772), NZPh3 (DQ094773), NZPh5 (DQ094774), NZPh6 (DQ094775), NZPh7 (DQ094776), NZPh9 (DQ094777), NZCt4 (DQ094780), NZSb7 (DQ094778), and NZSb9 (DQ094779). The complete sequence of "Ca. P. australiense" tuf gene (DQ096804) was obtained from isolate NZSb11 as part of a " $\mathrm{Ca}$. P. australiense" genome sequencing project. Sequences of the 16S-23S rRNA spacer region deposited in GenBank (with accession numbers) are NZPh6 (DQ286404), NZPh2 (DQ286405), NZPh4a (DQ286406), NZPh4b (DQ286407), NZCt1a (DQ286408), NZCt1b (DQ286409), NZSb10a (DQ286410), NZSb11b (DQ286411), NZSb10b (DQ286412), and NZSb11a (DQ286413). Suffixes "a" and "b" refer to the different operons from the same isolate. Ambiguity codes are given for positions where interoperon differences were not able to be resolved. 16S rRNA sequences used for comparison were PYL rrnA (U43569), PYL rrnB (U43570), PDB (Y10095), SGP (AJ243044), SLY (AJ243045), and AGY (X95706).

Sequence analysis. Sequences were analyzed using Sequencher (version 4.0.5; Gene Codes Corporation, Ann Arbor MI) and Vector NTI 9.0.0 InforMax (Invitrogen), and aligned using Clustal_X (46). Phylogenetic trees were inferred using parsimony as implemented within PAUP* (45). Rates of change in synonymous $\left(K_{\mathrm{S}}\right)$ and nonsynonymous $\left(K_{A}\right)$ positions were calculated using the method of Nei and Gojobori (31) as implemented in DnaSP Version 4.0 (34).

\section{RESULTS}

The complete tuf gene sequence and estimation of divergence times. The complete sequence of the tuf gene (DQ096804) of isolate NZSb11 is 1,185 nucleotides in length, with a $\mathrm{G}+\mathrm{C}$ content of $36.5 \%$. The predicted gene product of 394 amino acids

TABLE 2. Primers designed to distinguish the tuf gene clades 1 and 2 of "Candidatus Phytoplasma australiense"

\begin{tabular}{lcll}
\hline & Clade & Position & \multicolumn{1}{c}{ Sequence 5'-3' } \\
\hline PaTC1F & 1 & $306-324$ & CATTCTAGTTGTTTCTGGT \\
PaTC1R & 1 & $858-843$ & GTCTTCTCGGTTAATC \\
PaTC2F & 2 & $306-324$ & TATTTTAGTTGTTTCTGGA \\
PaTC2R & 2 & $858-843$ & GTCTTCGCGGTTAATA \\
\hline
\end{tabular}

contains the three structural domains of elongation factor $\mathrm{Tu}$ (NCBI Conserved Domain Search). A BLASTP search of the nonredundant database at NCBI showed that this gene shared high homology with the tuf gene from onion yellows (NC 005303, 95\% amino acid identity) and aster yellows witches'-broom (AY277404, 94\% identity) phytoplasmas. The degree of homology was significantly lower with apple proliferation (APR011104, $71 \%$ identity) and loofah witches'-broom (AF086617, 61\% identity) phytoplasmas.

A substitution rate for the phytoplasma tuf gene was calculated by comparing the full-length tuf gene sequence of the Loofah witches'-broom phytoplasma with that of " $C a$. P. australiense", two phytoplasmas that reflect the maximum divergence of the genus "Candidatus Phytoplasma" (41). From this, the average number of substitutions per synonymous sites $\left(K_{\mathrm{S}}\right)$ was estimated at $0.5465(147 / 269)$ substitutions per position. Based on the rate of change of the 16S rRNA gene, it has been proposed that the Phytoplasma clade arose approximately 180 million years ago (MYA), and that the time to the common ancestor for all phytoplasmas was $\approx 110$ MYA (28). Using this estimate, we calculate the evolutionary rate of the phytoplasma tuf gene to be $5.0 \times 10^{-9}$ substitutions per position per year.

Tuf gene sequences. PCR fragments of the tuf gene from 36 isolates of " $\mathrm{Ca}$. P. australiense" were generated by primers fTuf AY and rTuf AY, sequenced, and compared. Nineteen polymorphic sites were detected over an 815-bp region (between nucleotide positions 195 to 1009 , based on the complete gene sequence). The sequence of the tuf gene from the 36 isolates could be grouped into nine different variants, I to IX (Table 3). The nine variants clustered into two distinct groups, which differ at 10 or more of the 19 variable sites. The greatest difference between any two samples was at 16 positions, corresponding to a maximum divergence of $2.0 \%$ at a nucleic acid level. Considering the NZ isolates, the predicted amino acid sequences of variants VII and VIII were identical over the sequenced region. The other variants differed by one (variants III, IV, V, VI, and IX) or two (variants I and II) amino acids from the predicted consensus amino acid sequence. The maximum divergence at an amino acid level among all NZ samples was $1.1 \%(3 / 272)$.

A phylogenetic tree of the "Ca. P. australiense" tuf gene nucleotide sequences was created using the 36 samples from NZ augmented with 7 from Australia (44). The sequences separated into three distinct clades (Fig. 1). Clade 1 (including variants VIII and IX) contains isolates from both countries, clade 2 (including

TABLE 3. Nucleotide polymorphisms in the tuf gene of "Candidatus Phytoplasma australiense" in isolates from Australia and NZ (variant groups I to IX) between positions 195 and $1008^{\mathrm{a}}$

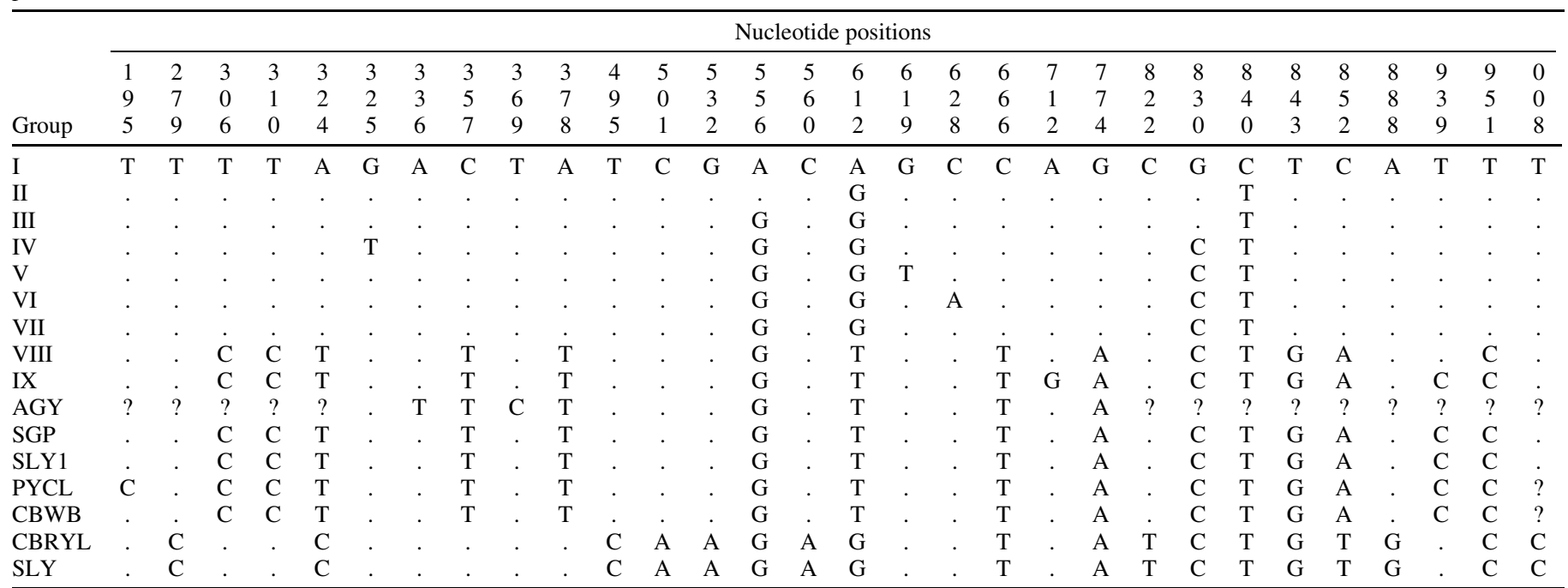

a Nucleotide positions are in accordance with the complete gene sequence of " $\mathrm{Ca}$. P. australiense" (DQ096804). Only polymorphic sites are shown. A dot indicates no difference from variant group I (top row) and missing data is indicated with a question mark (?). 
variants I to VII) consists exclusively of isolates from NZ, and clade 3 comprises two representatives only, both from Australia.

No simple relationship is apparent between variants and host or geographical location (Table 4). Variants I to VI (clade 2) are only reported from naturally growing stands of Phormium spp., and each was found at only one or two widespread localities. Variant VII (clade 2) was found in all hosts, with all samples within the Auckland-Coromandel and nearby Bay of Plenty-Waikato re- gions, within an approximately circular area of radius $80 \mathrm{~km}$. The sample from Phormium spp. was from a natural stand, those from Coprosma and Cordyline spp. were from restoration plantings, and those from strawberry from intensively managed beds. Both clade 1 variants also were reported from this same general area, with variant VIII reported only from strawberry beds and variant IX from naturally growing Phormium, Coprosma, and Cordyline spp. as well as strawberry.

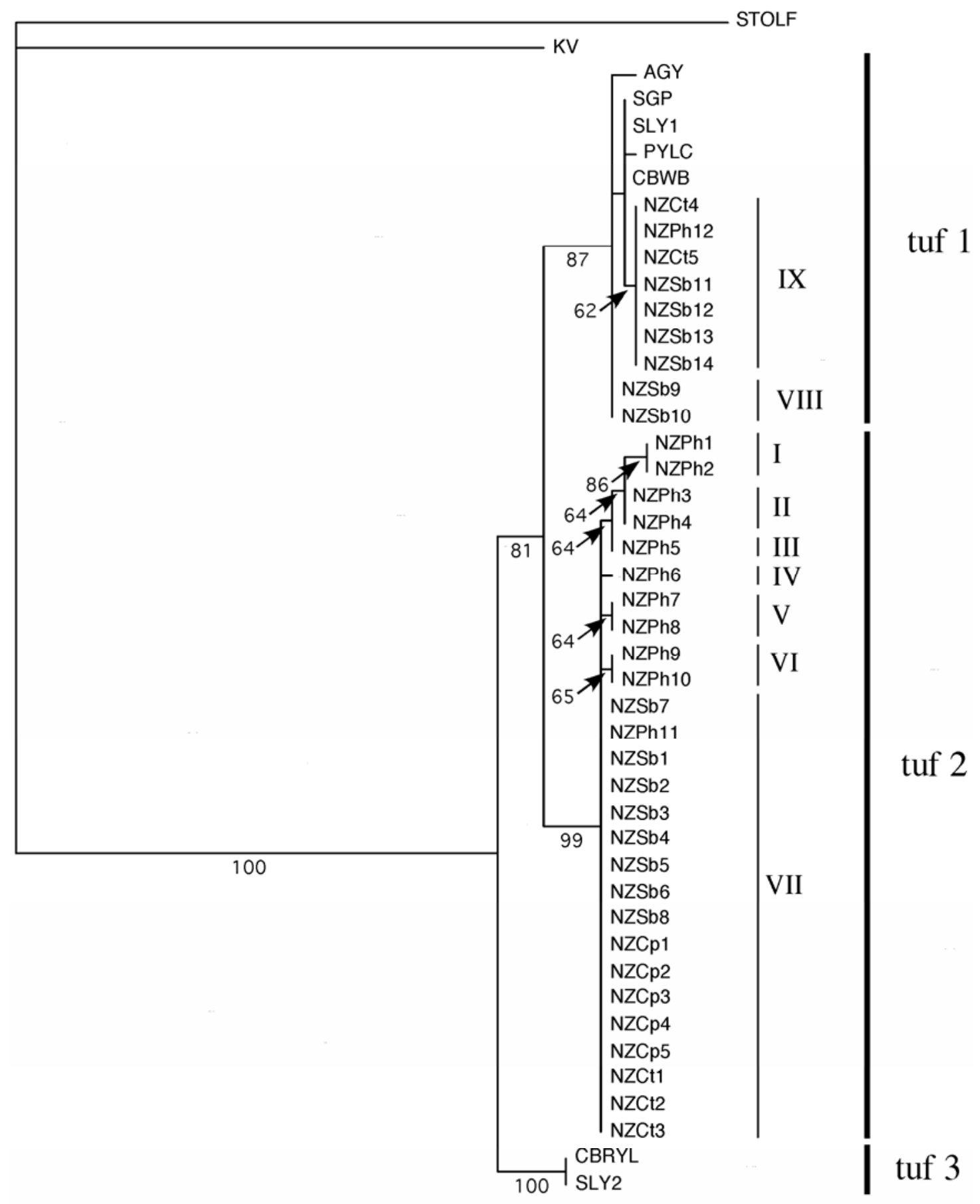

Fig. 1. Phylogenetic tree constructed by parsimony as implemented within PAUP* (45) of near full-length tuf gene sequences of "Candidatus Phytoplasma australiense" from Australia and New Zealand. New Zealand samples (prefixed with "NZ") consist of 815-bp fragments, as follows: NZPh1, NZPh2, NZPh3, NZPh4, NZPh5, NZPh6, NZPh7, NZPh8, NZPh9, NZPh10, NZPh11, NZPh12, NZCp1, NZCp2, NZCp3, NZCp4, NZCp5, NZCt1, NZCt2, NZCt3, NZCt4, NZCt5, NZSb1, NZSb2, NZSb3, NZSb4, NZSb5, NZSb6, NZSb7, NZSb8, NZSb9 NZSb10, NZSb11, NZSb12, NZSb13, and NZSb14 (accession numbers, provided in Table 1). Australian samples AGY, Australian grapevine yellows; SGP, strawberry green petal; SLY1, strawberry lethal yellows; SLY2, strawberry lethal yellows; PYLC, pumpkin yellow leaf curl; CBWB, cottonbush witches'-broom; and CBRYL, cottonbush reduced yellow leaves were obtained from GenBank. STOLF, Stolbur and KV, Clover phyllody were used as outgroups (for accession numbers, see Materials and Methods). The tree is one of 228 shortest trees of length 183. Bootstrap values generated from 1,000 bootstrap replicates are shown under branches or with arrows. 
Tuf clade 1- and 2-specific PCR. Using the sequence data, four primers (two forward and two reverse) were designed to distinguish tuf clade 1 from tuf clade 2 . The primers were tested on 11 samples (NZPh2, NZPh4, NZPh6, NZPh9, NZPh10, NZSb1, NZCt1, NZSb10, NZPh12, NZCt5, and NZSb11) and confirmed the classification as determined by sequence. All samples gave appropriate size bands for the designated primers. No sample gave bands for both types, suggesting the absence of mixed infections of tuf clade 1 and tuf clade 2 phytoplasmas.

Molecular clock analysis. We calculated the time of divergence of the different clades based on our estimated substitution rate (Table 5). Estimates were 9 MYA for the common ancestor of tuf clade 1 and tuf clade 2, 6 MYA for the ancestor of tuf clade 2 and tuf clade 3 , and 7 MYA for the ancestor of tuf clade 1 and tuf clade 3 . The time to common ancestor for the tuf clade 2 was estimated at $\approx 2$ MYA, and for tuf clade 1 at $\approx 0$ MYA, reflecting the limited variation in the latter clade.

16-23S ITS region. The ITS regions of 10 isolates were sequenced and compared to establish whether variations in this region reflect the phylogeny observed for the tuf gene. Of approximately 12 polymorphic sites identified among isolates, only 5 were informative with respect to phylogeny. These five positions consisted of single base insertions or deletions (INDELS) linked to small mononucleotide tracks, and were associated with either tuf clade 1 or tuf clade 2. All INDELS occurred outside the tRNA $^{\text {Ile }}$ that lies between positions 1576 and 1652. Five distinct types (A to E) were identified when INDELS were used as distinguishing criteria (Table 6). All those belonging to tuf clade 2 (seven samples) were homogeneous with respect to the five INDELS, whereas all tuf clade 1 (three isolates) were heterogeneous (Table 7). Isolate NZCt1 differed from all other isolates at positions 1691 and 1740 .

\section{DISCUSSION}

This study presents a comprehensive survey of sequence variation of the tuf gene from NZ isolates of " $C a$. P. australiense". These isolates fall into two distinct clades, each comprising a number of variants. Although the $16 \mathrm{~S}-23 \mathrm{~S}$ spacer region showed less variation between isolates compared with the tuf gene, the groupings that the spacer region reveals were consistent with most variants in tuf clade 2 being identical and variants VIII and IX in tuf clade 1 differing from these and from each other (Table 7). The only exception was variant VII, where isolate NZCt1 differed from all other samples analyzed. Coupled with evidence from other phytoplasmas that tuf gene variation usually matches $16 \mathrm{~S}$ rRNA variation but provides greater resolution (40), we conclude that these two tuf gene clades reflect two subspecific taxonomic groups present in NZ. In conformity with present usage $(20,40)$, we refer to these as subgroups.

This conclusion supports and extends results involving mainly Australian isolates. Schneider et al. (36) first recognized variation in the tuf gene in " $\mathrm{Ca}$. P. australiense" by RFLP analysis using the restriction enzyme HpaII to distinguish between a grape (AGY) sample from Australia from a Phormium sp. (PYL) sample from NZ. More recently, Streten and Gibb (43) extended this work, recognizing three subgroups based primarily on tuf gene variation, and our findings confirm this conclusion. Their subgroup 'tuf-Australia I' included isolates from pumpkin, papaya, grapevine, Gomphocarpus spp., and strawberry in Australia, their 'tufNew Zealand I' isolates from strawberry and Gomphocarpus in Australia, and their 'tuf-New Zealand II' an isolate from Phormium spp. in New Zealand. RFLP analysis of the ribosomal protein gene operon in isolates from their tuf-Australia I and tufNew Zealand I supported the recognition of these subgroups and also identified a further possible subgroup represented by an isolate from mung bean, the only isolate in the study from Western Australia (43). However, no tuf gene or 16S rRNA data has been presented for this latter isolate and further samples are desirable to substantiate this subgroup. Our phylogenetic analysis includes most of the sequences used in their study. Their tufAustralia I sequences, designated AGY, SGP, SLY1, PYLC, and CMWB, fall into our tuf clade 1 , and their tuf-New Zealand I sequences designated SLY2 and CBRYL comprise our tuf Clade 3. Their single tuf-New Zealand II sequence was our sequence NZPh3 in our tuf clade 2.

Streten and Gibb (43) grouped the two Australian isolates, SLY2 and CBRYL, as tuf-New Zealand I. However we did not find such sequences among our isolates of NZ phytoplasmas. Although these isolates are from Australia, they presumably were named 'tuf New Zealand' because they share the same RFLP pattern using restriction enzyme HpaII with isolate NZPh3 (PYL in their study). The PCR fragment generated by primers fTufAY and rTufAY has one HpaII site for those isolates in tuf clade 1 and two HpaII sites in tuf clades 2 and 3. The HpaII sites in tuf clades 2 and 3 , however, are not identical, because tuf clade 2 has sites at 491 and 666, whereas tuf clade 3 has sites at 491 and 888. Thus, the predicted fragment sizes are very similar and would be difficult to distinguish by gel electrophoresis. This difficulty

TABLE 5. Estimates of time to common ancestor using the number of synonymous nucleotide changes in the tuf gene of "Candidatus phytoplasma"

\begin{tabular}{llc}
\hline Comparison & \multicolumn{1}{c}{ Isolate } & Time (MYA) \\
\hline Tuf 1 vs. tuf 1 & NZSb11 vs. NZSb9 & 0.0 \\
Tuf 2 vs. tuf 2 & NZSb7 vs. NZPh1 & 1.86 \\
Tuf 1 vs. tuf 2 & NZSb7 vs. NZSb11 & 9.30 \\
Tuf 1 vs. tuf 3 & NZSb11 vs. CBRYL & 7.46 \\
Tuf 2 vs. tuf 3 & NZSb7 vs. CBRYL & 5.60 \\
Tuf 2 vs. outgroup & NZSb7 vs. Stolbur & 74.94 \\
Tuf 1 vs. outgroup & NZSb11 vs. Stolbur & 73.07 \\
Tuf 3 vs. outgroup & CBRYL vs. Stolbur & 66.72 \\
Outgroup vs. outgroup & STOLF vs. KV & 84.52
\end{tabular}

${ }^{\text {a }}$ MYA $=$ million years ago. Evolutionary rate for phytoplasma tuf gene was estimated to be $5.0 \times 10^{-9}$ nucleotide substitutions per position per year.

TABLE 4. Numbers of New Zealand isolates of "Candidatus Phytoplasma australiense" within each tuf gene variant group according to plant host and geographic region

\begin{tabular}{|c|c|c|c|c|c|c|c|c|c|c|}
\hline & \multicolumn{9}{|c|}{ Variant group } & \multirow[b]{2}{*}{ Total } \\
\hline & I & II & III & IV & $\mathrm{V}$ & VI & VII & VIII & IX & \\
\hline \multicolumn{11}{|l|}{ Host } \\
\hline Phormium spp. & 2 & 2 & 1 & 1 & 2 & 2 & 1 & $\ldots$ & 1 & 12 \\
\hline Strawberry & $\ldots$ & $\ldots$ & $\ldots$ & $\ldots$ & $\ldots$ & $\ldots$ & 8 & 2 & 4 & 14 \\
\hline Coprosma spp. & $\ldots$ & $\ldots$ & $\ldots$ & $\ldots$ & $\ldots$ & $\ldots$ & 5 & $\ldots$ & 1 & 6 \\
\hline Cordyline spp. & $\ldots$ & $\ldots$ & $\ldots$ & $\ldots$ & $\ldots$ & $\ldots$ & 3 & $\ldots$ & 2 & 5 \\
\hline \multicolumn{11}{|l|}{ Region } \\
\hline Northland & $\ldots$ & 2 & $\ldots$ & 1 & $\ldots$ & $\ldots$ & $\ldots$ & .. & $\ldots$ & 3 \\
\hline Auckland/Coromandel & 2 & $\ldots$ & $\ldots$ & $\ldots$ & $\ldots$ & $\ldots$ & 9 & $\ldots$ & 2 & 13 \\
\hline BoP/Waikato & $\ldots$ & $\ldots$ & 1 & $\ldots$ & $\ldots$ & $\ldots$ & 8 & 2 & 6 & 17 \\
\hline Taupo/Wellington & $\ldots$ & $\ldots$ & $\ldots$ & $\ldots$ & $\ldots$ & 2 & $\ldots$ & $\ldots$ & $\ldots$ & 2 \\
\hline Nelson & $\ldots$ & $\ldots$ & $\ldots$ & $\ldots$ & 2 & $\ldots$ & $\ldots$ & $\ldots$ & $\ldots$ & 2 \\
\hline
\end{tabular}


could be overcome for rapid identification of isolates by PCR using clade-specific primers, as we have demonstrated for tuf clades 1 and 2 (Table 2), with the added advantage that it would allow ready detection of mixed infections. Sequence analysis of the tuf clade 3 isolates indicates that they will not be amplified by the proposed combinations of primers. The subgroup terminology introduced by Streten and Gibb (43) is confusing because, as discussed, their tuf-Australia I clade now includes NZ isolates, and no tuf-New Zealand I subgroup isolates have been found in NZ. Thus, we suggest referring to the subgroups as 'tuf 1', 'tuf 2', and 'tuf 3 '.

Subgroups tuf 1 and tuf 2 can be distinguished by diagnostic PCR (Table 2). The variation we observed within tuf 1 (variant groups VIII and IX) and tuf 2 (variant groups I and VII) was minimal compared with the variation between the clades and does not compromise the use of the diagnostic primers described here.

Phylogeographic analysis is a powerful approach to understanding biogeographic distribution patterns (4), but has been little used with bacteria because many taxa presumably are dispersed readily worldwide. However, host-restricted groups such as the rhizobia (33) and the mollicutes offer opportunities for this approach. We estimated that the evolutionary rate for the tuf gene of phytoplasmas (based on synonymous substitutions) was $5.0 \times$ $10^{-9}$ substitutions per position per year. This rate is comparable to the proposed tuf gene evolutionary rate for the genus Buchnera, bacterial endosymbionts of aphids, which was estimated to be between 3.9 to $8.0 \times 10^{-9}(7)$. Both rates are significantly higher than for free-living bacteria such as Escherichia coli and Salmonella typhimurium (7). Reasons advanced for such differences include the absence of selective codon preference, the influence of Muller's ratchet $(7,8)$, and the higher mutation rate for endocellular symbionts (17). That the evolutionary rate for the $t u f$ gene of " $\mathrm{Ca}$. Phytoplasma" appears similar to that of Buchnera spp. is not entirely surprising. Phytoplasmas share a number of features with Buchnera spp., including small, A+T-rich genomes as a result of genome reduction from free-living ancestors. Both genera comprise obligate intracellular parasites or symbionts of insects, although phytoplasmas are also parasites of plants. Furthermore, both consist of small populations with limited ability to correct genetic errors through heterologous or homologous recombination, and with significant bottlenecks in their respective lifecycles. Although these similarities are a result of convergent evolution, they are the conditions that will result in increased fixation of mutations by the process of Muller's Ratchet $(7,47)$.

Previously, we have suggested that " $\mathrm{Ca}$. P. australiense" is indigenous to NZ, based on its widespread occurrence in that country in naturally growing stands of the endemic host Phormium spp., its early reported occurrence as PYL disease in 1908, its transmission by the endemic planthopper Oliarus atkinsoni, and the existence in the Phormium spp. population of genetically based disease resistance (25). The widespread but localized distribution of tuf variants I to VI (Tables 1 and 4), which presently are known only from Phormium spp., is supportive of this conclusion. However, although we have suggested previously that " $\mathrm{Ca}$.
P. australiense" may have been transported from NZ to Australia in infected rhizomes of Phormium spp. prior to the emergence of associated diseases there (25), our present findings indicate a more complex historical scenario. The basal position of the subgroup tuf 3, which contains only Australian isolates (Fig. 1), indicates that the species " $\mathrm{Ca}$. P. australiense" may have arisen in Australia, ultimately from an ancestor in the stolbur group. Although our molecular clock estimates undoubtedly are imprecise, and limited by the number and diversity of isolates examined, they indicate that the common ancestor of tuf 1 and tuf 2 diverged from tuf 3 perhaps 6 to 9 MYA, during the Miocene, clearly well after the separation of NZ from Australia, which occurred $\approx 80$ MYA in the Cretaceous (35). Subgroup tuf 2, which comprises only NZ isolates, may reflect an ancient long-distance dispersal event from Australia to NZ, perhaps involving wind dispersal of an infected insect vector. The divergence within this subgroup indicates that these isolates shared a common ancestor 1 to 2 MYA in the Pliocene to Pleistocene, indicating that this dispersal event probably took place before this time. The origins of subgroup tuf 1 are more debatable. Although none of the NZ isolates match those from Australia exactly, we suggest that the presence of isolates of this clade in both countries reflects at least one recent dispersal event. If the common ancestor of subgroups tuf 1 and tuf 2 dispersed to $\mathrm{NZ}$ prior to their divergence, then this dispersal would be consistent with the proposal of recent, humanmediated movement in Phormium rhizomes from NZ to Australia. On the other hand, if the divergence of subgroup tuf 1 from the common ancestor occurred in Australia, a scenario consistent with the early dispersal of subgroup tuf 2 , then our findings are consistent with recent potentially human-mediated dispersal from Australia to NZ. This could have occurred, for example, through the exchange of infected strawberry or other plants prior to the imposition of modern quarantine procedures. Clarification of the occurrence of " $\mathrm{Ca}$. P. australiense" infecting native plant hosts in Australia will help distinguish these hypotheses.

It was anticipated that study of phytoplasma variation might help illuminate reasons for the apparent emergence of new diseases in NZ since the 1970s. Both SLY, first recognized in the late

TABLE 7. Correlation between 16-23S rRNA spacer region and tuf types

\begin{tabular}{lccc}
\hline Isolate & $T u f$ variant group & $T u f$ gene clade & SR type $^{\text {a }}$ \\
\hline NZPh2 & I & 2 & A-A \\
NZPh4 & II & 2 & A-A \\
$\ldots$ & III & 2 & ND \\
NZPh6 & IV & 2 & A-A \\
$\ldots$ & V & 2 & ND \\
NZPh9, NZPh10 & VI & 2 & A-A \\
NZSb1 & VII & 2 & A-A \\
NZCt1 & VII & 2 & B-B \\
NZSb10 & VIII & 1 & C-D \\
NZPh12, NZSb11 & IX & 1 & D-E \\
\hline
\end{tabular}

${ }^{a}$ The two spacer region (SR) operons of all tuf 2 samples were homogeneous for insertion and deletions, whereas those for the tuf 1 isolates were heterogeneous; $\mathrm{ND}=$ not determined.

TABLE 6. Positions of insertion and deletions (INDELS) in the 16-23S rRNA spacer region (SR) ${ }^{\mathrm{a}}$

\begin{tabular}{lcccccc}
\hline & \multicolumn{5}{c}{ Nucleotide positions of INDELS in mononucleotide tracks. } \\
\cline { 2 - 6 } SR type & 1536 & 1583 & 1696 & 1707 & 1756 & Representative isolates \\
\hline A & - & - & - & T & G & NZPh2 \\
B & - & - & - & - & - & NZCt1 \\
C & - & - & A & T & G & NZS10b \\
D & - & T & A & T & G & NZSb11b \\
E & A & - & T & N & & \\
\hline
\end{tabular}

${ }^{a}$ Five different sequences were identified and are labeled A to E. All INDELS are associated with short mononucleotide tracks. Positions are arbitrarily assigned to the 5' end of the mononucleotide run as they relate to the sequence of SR type A. These positions will vary for the other types in accordance with insertions and deletions. Nucleotide positions are based on the first base of the 16S rRNA sequence of Oenothera aster yellows (M30790) being position 1. Dash (-) indicates absence of a nucleotide at INDEL site. 
1970s (49), and CSD, first recognized in the 1980s (2), are conspicuous diseases unlikely to have been overlooked much prior to these years. On the other hand, CLD is more inconspicuous, but there are indications it also emerged in the 1970s, and we have proposed that infected Coprosma robusta acts as an infection source for the diseases of strawberry and Cordyline spp., which probably are terminal hosts that do not act as sources for further vector infection (5). The association of these "new" diseases with only three of the nine tuf variants recognized here provides some support for this proposal. Variants VII and IX both have been found in Coprosma and Cordyline spp. and strawberry, as well as Phormium spp., in the same geographic area (Table 4), and the third variant, variant VIII, is known only from two strawberry samples also in this area. The only known vector of " $\mathrm{Ca}$. P. australiense" is $O$. atkinsoni, which largely is restricted to Phormium spp. $(10,24)$. This suggests that at least one other vector is associated with transmission to other hosts (5). Although $O$. atkinsoni occasionally may feed on other plant species, thereby transmitting variants from Phormium spp. to other hosts such as Coprosma spp., widespread dissemination from such a "new" host is likely due to this second, presumably polyphagous, vector. Such a hypothesis implies that variants VII, VIII, and IX originate in Phormium spp. Although this is plausible for variant VII, as part of the NZ-restricted tuf 2, it is not necessarily so for variants VIII and IX, especially if they have arrived recently in NZ from Australia. A better understanding of the ecology of these diseases must await identification of the insect vector or vectors associated with transmission

\section{ACKNOWLEDGMENTS}

Funds for this research were provided by the New Zealand Foundation for Research, Science and Technology. The complete sequence of "Ca. P. australiense" tuf gene was obtained as part of a " $\mathrm{Ca}$. P. australiense" genome sequencing project (Marsden Fund, Royal Society of New Zealand, Contract No. GRD001).

\section{LITERATURE CITED}

1. Ahrens, U., and Seemüller, E. 1992. Detection of DNA of plant pathogenic mycoplasmalike organisms by a polymerase chain reaction that amplifies a sequence of the 16S rRNA gene. Phytopathology 82:828-832.

2. Andersen, M. T., Beever, R. E., Sutherland, P. W., and Forster, R. L. S 2001. Association of 'Candidatus Phytoplasma australiense' with sudden decline of cabbage tree in New Zealand. Plant Dis. 85:462-469.

3. Andersen, M. T., Longmore, J. L., Liefting, L. W., Wood, G. A., Sutherland, P. W., Beck, D. L., and Forster, R. L. S. 1998. Phormium yellow leaf phytoplasma is associated with strawberry lethal yellows disease in New Zealand. Plant Dis. 82:606-609.

4. Avise, J. C. 2000. Phylogeography: The History and Formation of Species. Harvard University Press, Cambridge, MA.

5. Beever, R. E., Wood, G. A., Andersen, M. T., Pennycook, S. R., Sutherland, P. W., and Forster, R. L. S. 2004. 'Candidatus Phytoplasma australiense' in Coprosma robusta in New Zealand. N.Z. J. Bot. 42:663675 .

6. Berg, M., and Seemüller, E. 1999. Chromosomal organization and nucleotide sequence of the genes coding for the elongation factors $\mathrm{G}$ and Tu of the apple proliferation phytoplasma. Gene 226:103-109.

7. Brynnel, E. U., Kurland, C. G., Moran, N. A., and Andersson, S. G. E. 1998. Evolutionary rates for tuf genes in endosymbionts of aphids. Mol. Biol. Evol. 15:574-582.

8. Canbäck, B., Tamas, I., and Andersson, S. G. E. 2004. A phylogenomic study of endosymbiotic bacteria. Mol. Biol. Evol. 21:1110-1122.

9. Crosby, T. K., Dugdale, J. S., and Watt, J. C. 1998. Area codes for recording specimen localities in the New Zealand subregion. N.Z. J. Zool. 25:175-183.

10. Cumber, R. A. 1953. Investigations into yellow-leaf disease of Phormium. IV. Experimental induction of yellow-leaf condition in Phormium tenax Forst. by the insect vector Oliarus atkinsoni Myers (Hem., cixiidae). N. Z. J. Sci. Technol. 34:31-40.

11. Davis, R. E., Dally, E. L., Gundersen, D. E., Lee, I. M., and Habili, N. 1997. "Candidatus phytoplasma australiense," a new phytoplasma taxon associated with Australian grapevine yellows. Int. J. Syst. Bacteriol. 47:262-269.
12. Davis, R. I., Jacobson, S. C., De La Rue, S. J., Tran-Nguyen, L., Gunua, T. G., and Rahamma, S. 2003. Phytoplasma disease surveys in the extreme north of Queensland, Australia, and the island of New Guinea. Australas. Plant Pathol. 32:269-277.

13. Deng, S., and Hiruki, C. 1991. Amplification of $16 \mathrm{~S}$ rRNA genes from culturable and nonculturable Mollicutes. J. Microbiol. Methods 14:53-61.

14. Gardiner, S. E., Bassett, H. C. M., Noiton, D. A. M., Bus, V. G., Hofstee, M. E., White, A. G., Ball, R. D., Forster, R. L. S., and Rikkerink, E. H. A. 1996. A detailed linkage map around an apple scab resistance gene demonstrates that two disease resistance classes both carry the $\mathrm{V}_{\mathrm{f}}$ gene. Theor. Appl. Genet. 93:485-493.

15. Gibb, K. S., Persley, D. M., Schneider, B., and Thomas, J. E. 1996. Phytoplasmas associated with papaya diseases in Australia. Plant Dis. 80:174178.

16. Gundersen, D. E., Lee, I. M., Rehner, S, A., Davis, R. E., and Kingsbury, D. T. 1994. Phylogeny of mycoplasmalike organisms (phytoplasmas): A basis for their classification. J. Bacteriol. 176:5244-5254.

17. IRPCM Phytoplasma/Spiroplasma Working Team, P. T. G. 2004. 'Candidatus Phytoplasma', a taxon for the wall-less, non-helical prokaryotes that colonize plant phloem and insects. Int. J. Syst. Evol. Microbiol. 54:1243-1255.

18. Itoh, T., Martin, W., and Nei, M. 2002. Acceleration of genomic evolution caused by enhanced mutation rate in endocellular symbionts. Proc. Natl. Acad. Sci. USA 99(20):12944-12948.

19. Lathe, W. C., and Bork, P. 2001. Evolution of tuf genes: Ancient duplication, differential loss and gene conversion. FEBS Lett. 502:113-116.

20. Lee, I. M., Davis, R. E., and Gundersen-Rindal, D. E. 2000. Phytoplasma: Phytopathogenic Mollicutes. Annu. Rev. Microbiol. 54:221-255.

21. Lee, I.-M., Gundersen-Rindal, D. E., Davis, R. E., Bottner, K. D., Marcone, C., and Seemüller, E. 2004. 'Candidatus Phytoplasma asteris', a novel phytoplasma taxon associated with aster yellows and related diseases. Int. J. Syst. Evol. Microbiol. 54:1037-1048.

22. Lee, I. M., Hammond, R. W., Davis, R. E., and Gundersen, D. E. 1993. Universal amplification and analysis of pathogen 16S rDNA for classification and identification of mycoplasmalike organisms. Phytopathology 83:834-842.

23. Liefting, L. W., Andersen, M. T., Beever, R. E., Gardner, R. C., and Forster, R. L. S. 1996. Sequence heterogeneity in the two 16S rRNA genes of Phormium yellow leaf phytoplasma. Appl. Environ. Microbiol. 62:3133-3139.

24. Liefting, L. W., Beever, R. E., Winks, C. J., Pearson, M. N., and Forster, R. L. S. 1997. Planthopper transmission of Phormium yellow leaf phytoplasma. Australas. Plant Pathol. 26:148-154.

25. Liefting, L. W., Padovan, A. C., Gibb, K. S., Beever, R. E., Andersen, M. T., Newcomb, R. D., Beck, D. L., and Forster, R. L. S. 1998. 'Candidatus Phytoplasma australiense' is the phytoplasma associated with Australian grapevine yellows, papaya dieback and Phormium yellow leaf diseases. Eur. J. Plant Pathol. 104:619-623.

26. Lim, P.-O., and Sears, B. B. 1989. 16S rRNA sequence indicates that plant-pathogenic mycoplasmalike organisms are evolutionarily distinct from animal mycoplasmas. J. Bacteriol. 171:5901-5906.

27. Magarey, P. A., Plavsic, B., and Wachtel, M. F. 1988. MLO associated with Australian grapevine yellows diseased phloem cells. Int. J. Trop. Plant Dis. 6:175-179.

28. Maniloff, J. 2002. Phylogeny and evolution. Pages 31-43 in: Molecular Biology and Pathogenicity of Mycoplasmas. S. Razin and R. Herrmann, eds. Kluwer Academic/Plenum, New York.

29. McCoy, R. E., Caudwell, A., Chang, C. J., Chen, T.-A., Chiykowski, L. N., Cousin, M. T., Dale, J. L., de Leeuw, G. T. N., Golino, D. A., Hackett, K. J., Kirkpatrick, B. C., Marwitz, R., Petzold, H., Shina, R. H., Sugiura, M., Whitcomb, R. F., Yang, I. L., Zhu, B. M., and Seemüller, E. 1989. Plant diseases associated with mycoplasmalike organisms. Pages 545-560 in: The Mycoplasmas, vol. 5. R. F. Whitcomb and J. G. Tully, eds. Academic Press, New York.

30. Murray, R. G. E., and Schleifer, K. H. 1994. Taxonomic notes: A proposal for recording the properties of putative taxa of prokaryotes. Int. J. Syst. Bacteriol. 44:174-176.

31. Nei, M., and Gojobori, T. 1986. Simple methods for estimating the numbers of synonymous and nonsynonymous nucleotide substitutions. Mol. Biol. Evol. 3:418-426.

32. Padovan, A., Gibb, K., and Persley, D. 2000. Association of 'Candidatus Phytoplasma australiense' with green petal and lethal yellows diseases in strawberry. Plant Pathol. 49:362-369.

33. Parker, M. A., Doyle, J. L., and Doyle, J. J. 2004. Comparative phylogeography of Amphicarpea legumes and their root-nodule symbionts in Japan and North America. J. Biogeogr. 31:425-434.

34. Rozas, J., Sanchez-DelBarrio, J., Messeguer, X., and Rozas, R. 2003. DnaSP, DNA polymorphism analyses by the coalescent and other methods. Bioinformatics 19:2496-2497. 
35. Sanmartin, I., and Ronquist, F. 2004. Southern hemisphere biogeography inferred by event-based models: Plant versus animal patterns. Syst. Biol. 53:216-243.

36. Schneider, B., Gibb, K. S., and Seemüller, E. 1997. Sequence and RFLP analysis of the elongation factor Tu gene used in differentiation and classification of phytoplasmas. Microbiology 143:3381-3389.

37. Schneider, B., Padovan, A., De La Rue, S., Eichner, R., Davis, R., Bernuetz, A., and Gibb, K. 1999. Detection and differentiation of phytoplasmas in Australia: An update. Aust. J. Agric. Res. 50:333342.

38. Schneider, B., and Seemüller, E. 1994. Presence of two sets of ribosomal genes in phytopathogenic Mollicutes. Appl. Environ. Microbiol. 60:34093412.

39. Schneider, B., Seemüller, E., Smart, C. D., and Kirkpatrick, B. C. 1995. Phylogenetic classification of plant pathogenic mycoplasmalike organisms or phytoplasmas. Pages 369-380 in: Molecular and Diagnostic Procedures in Mycoplasmology. I. R. Razin and J. G. Tully, eds. Academic Press, San Diego, CA.

40. Seemüller, E., Garnier, M., and Schneider, B. 2002. Mycoplasmas of plant and insects. Pages 91-122 in: Molecular Biology and Pathogenicity of Mycoplasmas. S. Razin and R. Herrmann, eds. Kluwer Academic/ Plenum, New York.

41. Seemüller, E., Marcone, C., Lauer, U., Ragozzino, A., and Göschl, M. 1998. Current status of molecular classification of the phytoplasmas. J. Plant Pathol. 80:3-26.
42. Smart, C. D., Schneider, B., Blomquist, C. L., Guerra, L. J., Harrrison, N A., Ahrens, U., Lorenz, K. H., Seemüller, E., and Kirkpatrick, B. C. 1996. Phytoplasma-specific PCR primers based on sequences of the 16S-23S rRNA spacer region. Appl. Environ. Microbiol. 62:2988-2993.

43. Streten, C., and Gibb, K. 2005. Genetic variation in 'Candidatus Phytoplasma australiense'. Plant Pathol. 54:8-14.

44. Streten, C., Herrington, M. E., Hutton, D. G., Persley, D. M., Waite, G. K., and Gibb, K. S. 2005 Plant hosts of the phytoplasmas and rickettsialike-organisms associated with strawberry lethal yellows and green petal diseases. Australas. Plant Pathol. 34:165-173.

45. Swofford, D. 1998. PAUP* Phylogenetic Analysis Using Parsimony and Other Methods. Sinauer, Sunderland, MA.

46. Thompson, J. D., Gibson, T. J., Plewniak, F., Jeanmougin, F., and Higgins, D. G. 1997. The CLUSTAL_X windows interface: Flexible strategies for multiple sequence alignment aided by quality analysis tools. Nucleic Acids Res. 25:4876-4882.

47. Wernegreen, J. J. 2002. Genome evolution in bacterial endosymbionts of insects. Nat. Rev. Genet. 3:850-861.

48. White, D. T., Billington, S. J., Walsh, K. B., and Scott, P. T. 1997. DNA sequence analysis supports the association of phytoplasmas with papaya (Carica papya) dieback, yellow crinkle and mosaic. Australas. Plant Pathol. 26:28-36.

49. Wood, G. A. 1998. Virus and Virus-Like Diseases and Non-infectious Disorders of Small Fruits in New Zealand. Royal Society New Zealand, Wellington. 